\title{
A Study on the Physicochemical and Bacteriological Analysis of Sewage Water from Coastal Karnataka, India
}

\author{
Anusha Hoskere Chandrashekhara ${ }^{1}$, Sohan R Bangera ${ }^{2}$, Vignesh Shetty ${ }^{3}$, Suganthi M Devadas ${ }^{4}$, Poornima Bhagavath ${ }^{5}$, \\ Mamatha Ballal ${ }^{6}$
}

\begin{abstract}
Background and objectives: Water, the elixir of life, gets polluted by fecal contaminants, household wastes, and industrial effluents into sewage water and acts as a vehicle in the transmission of human diseases associated with microorganisms. The present study was carried out to isolate and identify the pathogenic microorganisms along with their antimicrobial resistance pattern and also to chemically analyze the sewage water sources of Udupi district.

Materials and methods: The 12 sewage water samples were collected from different localities and subjected to bacterial isolation, identification, and antimicrobial susceptibility testing (AST). The chemical analysis of $\mathrm{pH}$ value, total hardness, and amount of chloride present in the samples was determined.

Results: A total of 26 organisms were isolated which consisted of waterborne pathogens, Vibrio alginolyticus (V. alginolyticus) ( $n=2)$ and Aeromonas sobria (A. sobria) $(n=2)$ along with the environmental pathogens $(n=22)$. A. sobria showed resistance to cefotaxime and the other isolates were susceptible to the antimicrobial drug tested. The $\mathrm{pH}$ ranged from 5.7 to 7.5. Ten samples were considered as hard, and in two samples, the chloride content was above normal.

Conclusion: Contamination of groundwater with the sewage water poses a threat to human health. Hence, treating the sewage water in an appropriate sewage treatment plant (STP) is recommended and the need of the hour.

Keywords: Antimicrobial resistance, Bacterial isolation, Chloride, Hardness of water, $\mathrm{pH}$ value, Sewage water.

Journal of Gastrointestinal Infections (2019): 10.5005/jp-journals-10068-3027
\end{abstract}

\section{INTRODUCTION}

Water is an important factor essential for life but the quality of water can be compromised by the presence of infectious agents, toxic chemicals, and radiological hazards. Water acts as a vehicle in the transmission of human diseases associated with microorganisms. The waterborne diseases cause major health issues in most parts of the globe, owing to about 1.7 billion cases of diarrhea per year. Due to these waterborne diseases, children under the age of 5 years are the severely affected leading to increased morbidity and mortality. ${ }^{1}$ The sewage water consists of physical, chemical, and biological wastes which can be separated from water by various methods. The microbial flora of sewage water mainly comprises of bacteria, viruses, protozoa, algae, fungi, and helminths. ${ }^{2}$ Among the bacteria that contaminate water sources, Escherichia coli (E. coli) is frequently seen in sewage and waste waters, since it is the normal flora of the human and animal gut and can easily contaminate water bodies. ${ }^{3}$ The sewage water comprises of certain human toxic heavy metals to which these bacteria are resistant, such as chromium, cobalt, and nickel. ${ }^{4}$ The hardness of water is caused by divalent metal ions like calcium and magnesium. The chloride ion is an inorganic anion which is usually present in sewage and wastewater. The $\mathrm{pH}$ of water is to measure the intensity of acidic or basic character obtained from sewage or other water sources. Drug resistance has been acquired by some of these sewage bacteria in the due course of time. The transfer of antibiotic resistance genes is very frequently seen in sewage and lake waters due to pooling of antimicrobial resistant microorganisms. The transfer of genetic component responsible for drug resistance in Gram-negative bacteria is mainly through conjugation process. Some of the physicochemical parameters also lead to transfer of resistant genes among the microorganisms. ${ }^{5}$

\begin{abstract}
1-4,6 Department of Microbiology, Enteric Diseases Division, Kasturba Medical College, Manipal Academy of Higher Education, Manipal, Karnataka, India

${ }^{5}$ Department of Chemistry, Manipal Institute of Technology, Manipal Academy of Higher Education, Manipal, Karnataka, India

Corresponding Author: Mamatha Ballal, Department of Microbiology, Enteric Diseases Division, Kasturba Medical College, Manipal Academy of Higher Education, Manipal, Karnataka, India, Phone: +91 9901466320, e-mail: mamatha.ballal08@gmail.com
\end{abstract}

How to cite this article: Chandrashekhara AH, Bangera SR, Shetty V, et al. A Study on the Physicochemical and Bacteriological Analysis of Sewage Water from Coastal Karnataka, India. J Gastrointest Infect 2019;9(1):10-14.

Source of support: Nil

Conflict of interest: None

The collection of wastewater is usually done through underground sewage pipes to one or more centralized STPs, where the sewage water is treated. ${ }^{6}$ The spread of drug resistance is increasing in the developing countries due to inadequate usage of antibiotics. The wastewater treatment plants are connected to household and hospitals where more antibiotics are used and chances of bacteria acquiring drug resistance are high. Once these resistant organisms come in contact with wastewater treatment plants, they transfer the resistance to the endogenous microbial community. ${ }^{7}$ The present study was carried out to isolate and identify the pathogenic microorganisms along with their antimicrobial resistance pattern and also to chemically analyze the sewage water sources of Udupi district, Karnataka.

() The Author(s). 2019 Open Access This article is distributed under the terms of the Creative Commons Attribution 4.0 International License (https://creativecommons. org/licenses/by-nc/4.0/), which permits unrestricted use, distribution, and non-commercial reproduction in any medium, provided you give appropriate credit to the original author(s) and the source, provide a link to the Creative Commons license, and indicate if changes were made. The Creative Commons Public Domain Dedication waiver (http://creativecommons.org/publicdomain/zero/1.0/) applies to the data made available in this article, unless otherwise stated. 


\section{Materials and Methods}

\section{Bacteriological Analysis}

Sample Collection

The 12 sewage water samples were collected from different parts of Udupi district. Sampling was done in sterilized $100 \mathrm{~mL}$ bottle containing $0.1 \mathrm{~mL}$ of freshly added $1.8 \%$ aqueous solution of sodium thiosulfate. The water was collected from a depth of $30 \mathrm{~cm}$ with its mouth facing the water current. ${ }^{8}$ The samples were transported to the laboratory in ice and stored in $-80^{\circ} \mathrm{C}$ until used for further studies. Samples were stored in the $-80^{\circ} \mathrm{C}$ at Enteric Diseases Division, Central Research Lab, Kasturba Medical College, Manipal, until further processing.

\section{Isolation of Bacteria}

The samples were thawed at room temperature. Dilutions of 1:10 and 1:100 were performed. $10 \mu \mathrm{L}$ of undiluted, 1:10, and 1:100 diluted water samples were inoculated into $5 \%$ sheep blood agar and MacConkey agar by spread plate method. The culture plates were incubated at $37^{\circ} \mathrm{C}$ for $18-24$ hours. The water samples were also inoculated into alkaline peptone water, selenite $\mathrm{F}$ broth, and glucose broth and incubated at $37^{\circ} \mathrm{C}$ for 4 hours, 18 hours, and 24 hours, respectively, and subcultured into thiosulfate citrate bile salt sucrose agar (TCBS), Hektoen enteric agar (HEA), 5\% sheep blood agar, and MacConkey agar, which were further incubated for 24 hours at $37^{\circ} \mathrm{C}$ to look for the presence of enteric pathogens. Colonies were identified by Gram staining, and a battery of biochemical tests. ${ }^{9}$ Further confirmation and speciation was done by MALDI-TOF (Biomerieux).

\section{Antimicrobial Susceptibility Testing}

The AST was performed for the isolates by the Kirby-Bauer disc diffusion method according to clinical and laboratory standards institute (CLSI) guidelines. ${ }^{10}$ The antibiotics used for members of Enterobacteriaceae family were amikacin, ampicillin, amoxicillinclavulanic acid, ceftriaxone, ciprofloxacin, and cotrimoxazole; for Pseudomonadaceae family were ceftazidime, gentamicin, piperacillin, imipenem, amikacin, and ciprofloxacin; for Vibrionaceae family were tetracycline, ampicillin, cotrimoxazole, and ciprofloxacin; and for Aeromonas species, cefotaxime was included. The plates were incubated at $37^{\circ} \mathrm{C}$ for 24 hours. The zone of inhibition was measured and interpreted according to CLSI guidelines. ${ }^{11}$

\section{Chemical Analysis}

Determination of $\mathrm{pH}$

The $\mathrm{pH}$ or the hydrogen ion concentration was determined to check the intensity of acidic or basic property of water by the $\mathrm{pH}$ meter. ${ }^{12}$

\section{Determination of Total Hardness}

The hardness of the sewage water sample was determined by titration method. ${ }^{12}$

\section{Determination of Chloride}

The amount of chloride content present in sewage water sample was determined by titration method. ${ }^{12}$

\section{RESULTS}

Of the 12 sewage samples collected, a total of 26 bacterial pathogens were isolated as shown in Figure 1. The waterborne pathogens, A. sobria $(7.69 \%, n=2)$, and V. alginolyticus $(7.69 \%, n=2)$ were isolated among the other environmental pathogens. The other organisms predominantly seen were E. coli $(15.3 \%, n=4)$, Klebsiella pneumoniae, Pseudomonas species, and Acinetobacter johnsonii as shown in Table 1.

A. sobria showed resistance to cefotaxime. Out of four E. coli isolates, one of the $E$. coli isolate was resistant to ampicillin and cotrimoxazole, whereas the other one showed resistance to amoxicillin-clavulanic acid. An isolate of $A$. Iwoffii was resistant to piperacillin. The other isolates were susceptible to the antimicrobial agents tested as shown in Table 1.

The chemical analysis of $\mathrm{pH}$ determination showed a variable range of $\mathrm{pH}$ 5.7-7.5 that was interpreted as acidic, basic, and neutral. Of 12 sewage samples, 50\% (6/12) were neutral, $41.6 \%$ (5/12) were acidic, and one sample showed basic $\mathrm{pH}$. The total hardness of water was tested and ten samples were found to be hard (>200 ppm). The amount of chloride content present in water was detected and two samples were found to be above the normal range as shown in Table 2.

\section{Discussion}

The wastewater consists of feces and urine of both human beings and animals that carry many pathogenic organisms. Some of the human pathogenic bacteria usually seen in sewage water are Vibrio,

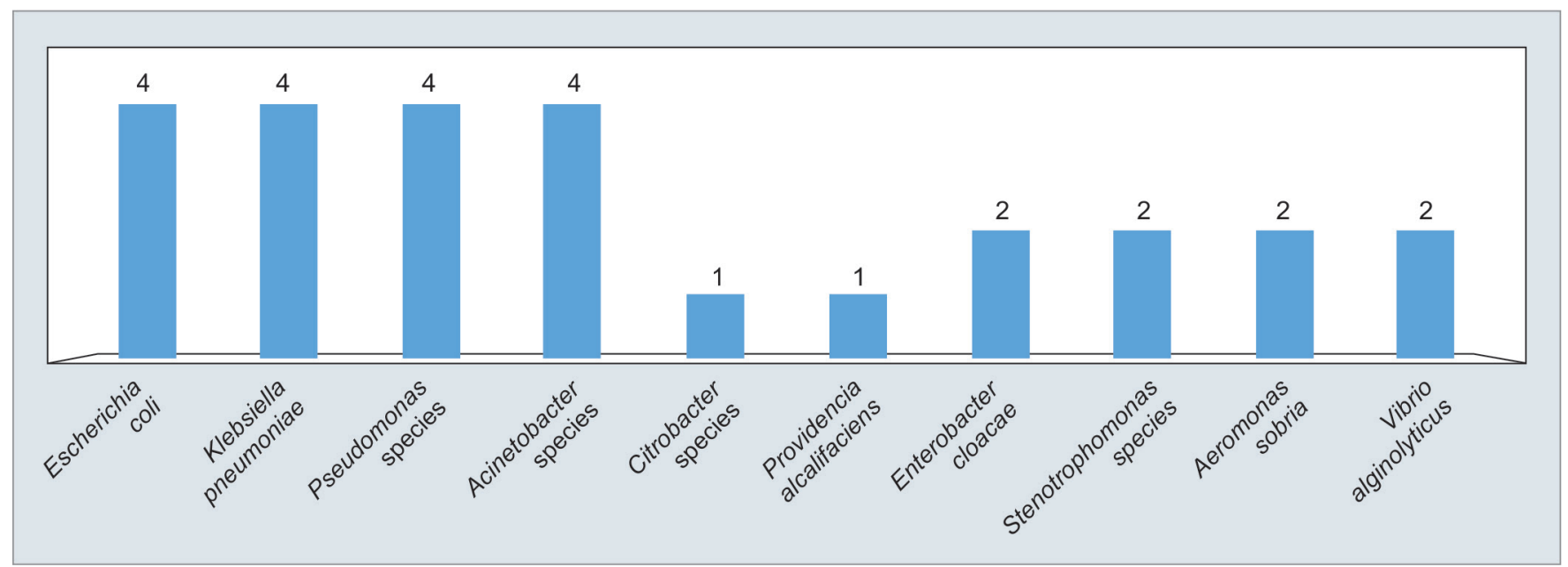

Fig. 1: Bacterial pathogens isolated from sewage samples 
Table 1: Sample site, organisms isolated, and their antimicrobial resistance pattern

\begin{tabular}{|c|c|c|c|}
\hline & Sampling site & Organism & Antimicrobial resistance \\
\hline \multirow[t]{2}{*}{1} & River & Escherichia coli & Amoxicillin-clavulanic acid \\
\hline & & Acinetobacter johnsonii & - \\
\hline 2 & Lake near highway & Vibrio alginolyticus & - \\
\hline \multirow[t]{3}{*}{3} & Open sewer line & Escherichia coli & - \\
\hline & & Klebsiella pneumoniae & - \\
\hline & & Pseudomonas aeruginosa & - \\
\hline \multirow[t]{2}{*}{4} & Open sewer line & Citrobacter braakii & - \\
\hline & & Acinetobacter /woffii & Piperacillin \\
\hline \multirow[t]{3}{*}{5} & Open sewage in the city near highway & Enterobacter cloacae & - \\
\hline & & Klebsiella pneumoniae & - \\
\hline & & Providencia alcalifaciens & - \\
\hline 6 & Lake & Stenotrophomonas maltophila & - \\
\hline 7 & Sewage outlet near highway & Vibrio alginolyticus & - \\
\hline \multirow[t]{2}{*}{8} & Sewage water outlet & Acinetobacter johnsonii & - \\
\hline & & Enterobacter cloacae & - \\
\hline 9 & Sewage outlet & Aerobic Spore Bearing bacilli & - \\
\hline \multirow[t]{3}{*}{10} & Sewage water outlet connected & Aeromonas sobria & Cefotaxime \\
\hline & & Pseudomonas mandocina & - \\
\hline & & Acinetobacter johnsonii & - \\
\hline \multirow[t]{4}{*}{11} & Sewage water connected to public toilet & Aeromonas sobria & Cefotaxime \\
\hline & & Escherichia coli & - \\
\hline & & Klebsiella pneumoniae & Amoxicillin-clavulanic acid \\
\hline & & Pseudomonas spp. & - \\
\hline \multirow[t]{4}{*}{12} & Sewage treatment plant & Escherichia coli & Ampicillin and cotrimoxazole \\
\hline & & Klebsiella pneumoniae & Amoxicillin-clavulanic acid \\
\hline & & Pseudomonas aeruginosa & - \\
\hline & & Stenotrophomonas maltophila & - \\
\hline
\end{tabular}

Table 2: Physicochemical values of the sewage water samples

\begin{tabular}{|c|c|c|c|c|c|c|}
\hline Sample no. & pHvalue & Interpretation & $\begin{array}{l}\text { Total } \\
\text { hardness (ppm) }\end{array}$ & Interpretation & Chloride (ppm) & Interpretation \\
\hline 1 & 6.8 & Neutral & 265 & Hard & 74.5 & Acceptable \\
\hline 2 & 6.1 & Acidic & 16,270 & Hard & 59.6 & Acceptable \\
\hline 3 & 7.1 & Neutral & 720 & Hard & 178.8 & Acceptable \\
\hline 4 & 7.1 & Neutral & 260 & Hard & 253.3 & Unacceptable \\
\hline 5 & 7.2 & Neutral & 265 & Hard & 193.7 & Acceptable \\
\hline 6 & 6.3 & Acidic & 265 & Hard & 178.8 & Acceptable \\
\hline 7 & 6.4 & Acidic & 686 & Hard & 89.4 & Acceptable \\
\hline 8 & 5.7 & Acidic & 420 & Hard & 305.4 & Unacceptable \\
\hline 9 & 6.1 & Acidic & 14,940 & Hard & 29.8 & Acceptable \\
\hline 10 & 7.5 & Basic & 79.5 & Soft & 149 & Acceptable \\
\hline 11 & 6.9 & Neutral & 360 & Hard & 149 & Acceptable \\
\hline 12 & 6.8 & Neutral & 180 & Soft & 149 & Acceptable \\
\hline
\end{tabular}

According to WHO: (a) pH value: 6.5-9.5, (b) total hardness: 200 ppm, and (c) chloride: 250 ppm $^{23}$

Aeromonas, E. coli, Shigella, Salmonella, Pseudomonas, and fecal streptococci due to fecal contamination. These organisms cause illness like cholera, typhoid, diarrhea, and dysentery. ${ }^{13}$

Our study showed that among 12 sewage water samples collected, the total bacterial isolates were 26 in number. In our study, the pathogenic $A$. sobria $(7.6 \%, n=2)$ was isolated from the sewage outlets, one near the beach and the other near public toilet.
Aeromonas species is usually present in aquatic and waste water, raw sewage, sewage effluents, sewage-contaminated waters, and activated sludge ${ }^{14}$ and is tolerant to high temperatures and basic $\mathrm{pH}$ and survives during summer. ${ }^{15}$ They cause gastrointestinal infection, wound infection, and also septicemia. Holmberg et al. ${ }^{16}$ reported the ability of Aeromonas species in untreated well water to cause gastrointestinal infection. The presence of Aeromonas 
species in aquatic environments is an alarming threat to public health as they are resistant to chlorination and can survive in aquatic systems, thereby acquiring virulence properties linked to human disease.

The other rare isolate was $V$. alginolyticus $(7.6 \%, n=2)$ and was isolated from two different sewage samples (one from lake and the other from a sewage outlet). The presence of $V$. alginolyticus from the lake suggests its habitat. ${ }^{17} \mathrm{~V}$. alginolyticus is a halophilic marine organism, which enters the human body and causes enteric diseases and extraintestinal infections such as otitis media, wound infections, sepsis, conjunctivitis, and tissue necrosis. It may be isolated from the stool specimen of a healthy person due to ingestion of contaminated raw seafood. It also causes infection in people who recently come in contact with sea water. ${ }^{18}$

The other pathogens isolated in our study were similar to a study by Moges et al. ${ }^{11}$ These pathogens cause gastrointestinal infection, urinary tract infection, cholecystitis, bacteremia, cholangitis, wound infection, and skin infections. ${ }^{19}$ There was no isolation of Gram-positive organisms in our study.

The bacterial isolates were tested for drug resistance. A. sobria showed resistance to cefotaxime. Studies have shown a diverse pattern of resistance for Aeromonas species and the urban wastewater effluents are thought to contribute to the antibiotic resistance seen in environmental Aeromonas. ${ }^{14}$ In our study, one of the $E$. coli isolate was resistant to amoxicillin-clavulanic acid and the other one was resistant to ampicillin and cotrimoxazole, respectively, which was similar to a study done in Austria for E. coli isolates from sewage and sludge. ${ }^{20}$ The environmental Acinetobacter species are generally susceptible to antimicrobial drugs when compared to the clinical isolates. In our study, an isolate of $A$. Iwoffii was resistant to piperacillin. This is in contrast to the study reported by Agrawal et al. ${ }^{21}$ There was no resistance seen for ciprofloxacin by any of the Gram-negative bacteria in our study, contradicting a study by Moges et al. ${ }^{11}$ in Northwest Ethiopia, where resistance to ciprofloxacin was $12 \%$. The chemical analysis of $\mathrm{pH}$ determination, total hardness, and chloride determination was performed for all the 12 sewage water samples. These tests are essential to evaluate the reliable indices of the toxic impact of effluents in the aquatic environment.

In a developing country, there are a very few wastewater treatment plants employed for treatment of sewage disposal and it is often observed that people below socioeconomic status have their dwelling near these sewage outlets. The untreated waste gets directly added to the water bodies such as rivers, lakes, ponds, and reservoirs, etc., polluting the fresh water of these regions and thereby making it unfit for consumption and usage. This also acts as a reservoir for the drug resistant pathogenic organisms, posing a global threat to mankind and health. The groundwater sources get contaminated by storage tank leakage, industrial waste, and sewer and septic leakage. ${ }^{21}$ Most of the antibiotics are incompletely metabolized by the patients after administration, and hence, they enter municipal sewage through patients' excreta. These drugs affect the biological process in STPs and may remain in the aquatic environment, causing an increase in the spread of drug resistance. ${ }^{22,23}$

Hence, the microbiological quality and safety of water systems is important and has to be maintained to prevent the high risks to human health. Furthermore, epidemiological studies in testing of water bodies should be undertaken to assess the potential risks to public health.

\section{Conclusion}

In the present study, sewage water samples were chemically analyzed and the pathogenic microorganisms were identified along with their antimicrobial resistance pattern. Contamination of drinking water or groundwater by the sewage water may cause a threat to human health. Resistance to antibiotics may be due to patients' excreta from the nearby hospitals which can lead to survival of bacteria and may spread to other water sources due to lack of treatment of sewage water. Hence, treating the sewage water in an appropriate STP is recommended and is the need of the hour.

\section{ACKnOWledgments}

The authors are thankful to Manipal University; Dean, Kasturba Medical College, Manipal; Enteric Disease Division, Central Research Lab, Kasturba Medical College, Manipal; Department of Chemistry, Manipal Institute of Technology, Manipal for providing all the facility and support to carry out this work.

\section{References}

1. Delgado-Gardea MC, Tamez-Guerra P, Gomez-Flores R, et al. Multidrug-resistant bacteria isolated from surface water in Bassaseachic Falls National Park, Mexico. Int J Environ Res public health 2016;13(6):597. DOI: 10.3390/ijerph13060597.

2. FAO.1997.chapter 2 health risks associated with wastewater use according to http://www.fao.org/docrep/w5367e/w5367e04.htm\# (accessed on 10 June 2017).

3. Costa EC, Arpini CM, Martins JDL. Antibiotic sensitivity profile of enteric bacteria isolated from beach waters and sewage from the municipality of Vila Velha-ES, Brazil. J Bacteriol Parasitology 2016;7:280.

4. Narasimhulu K, Rao PS, Vinod AV. Isolation and identification of bacterial strains and study of their resistance to heavy metals and antibiotics. J Microb Biochem Technol 2 1948;5948:074-076. OMICS Publishing Group, 10.4172/1948-5948.1000027.

5. Shakibaie MR, Jalilzadeh KA, Yamakanamardi SM. Horizontal transfer of antibiotic resistance genes among gram negative bacteria in sewage and lake water and influence of some physico-chemical parameters of water on conjugation process. J Env Biol 2009;30(1): 45-49.

6. Popa P, Timofti M, Voiculescu M, et al. Study of physico-chemical characteristics of wastewater in an urban agglomeration in Romania. Sci world J 2012;2012:549028. DOI: 10.1100/2012/549028.

7. Szczepanowski R, Linke B, Krahn I, et al. Detection of 140 clinically relevant antibiotic-resistance genes in the plasmid meta genome of wastewater treatment plant bacteria showing reduced susceptibility to selected antibiotics. Microbiology 2009;155(7):2306-2319. DOI: 10.1099/mic.0.028233-0.

8. Senior BW. Examination of water, milk, food and air. In: Mackie and McCartney, ed. Practical Medical Microbiology. 14th ed., New York, UK: Churchill Livingstone; 1996.

9. Yasin M, Ketema T, Bacha K. Physico-chemical and bacteriological quality of drinking water of different sources, Jimma zone, Southwest Ethiopia. BMC Res notes 2015;8(1):541. DOI: 10.1186/s13104-0151376-5.

10. CLSI performance standard for antimicrobial susceptibility in testing. 26th ed., CLSI supplement M100S. Wayns, PA: Clinical and Laboratory Standards Institution; 2016.

11. Moges F, Endris $\mathrm{M}$, Belyhun $\mathrm{Y}$, et al. Isolation and characterization of multiple drug resistance bacterial pathogens from waste water in hospital and non-hospital environments, Northwest Ethiopia. BMC Res Notes 2014;7(1):215. DOI: 10.1186/1756-0500-7-215. 
12. Jai Prakash BS, Venugopal R, Shivakumaraiah, et al. Water technology. In:Chemisrty for Engineering Students. Bangalore: Sree Offsets; 2006.

13. Omezuruike OI, Damilola AO, Adeola OT, et al. Microbiological and physicochemical analysis of different water samples used for domestic purposes in Abeokuta and Ojota, Lagos State, Nigeria. Afr J Biotechnol 2008;7(5):617.

14. Igbinosa IH, Igumbor EU, Aghdasi F, et al. Emerging Aeromonas species infections and their significance in public health. Sci World J 2012;2012:625023. DOI: 10.1100/2012/625023.

15. Monfort $P$, Baleux B. Dynamics of aeromonas hydrophila, aeromonas sobria, and aeromonas caviae in a sewage treatment pond. Appl Env Microbiol 1990;56(7):1999-2006.

16. Holmberg SD, Schell WL, Fanning GR, et al. Aeromonas intestinal infections in the United States. Ann Intern Med 1986;105(5):683-689. DOI: 10.7326/0003-4819-105-5-683.

17. Mustapha S, Mustapha EM, Nozha C. Vibrio alginolyticus: an emerging pathogen of foodborne diseases. Int J Sci Technol 2013;2(4):302-309.
18. Schmidt $\mathrm{U}, \mathrm{Chmel} \mathrm{HE}$, Cobbs CL. Vibrio alginolyticus infections in humans. J Clin Microbiol 1979;10(5):666-668.

19. Centers For Disease Control and Prevention. According to https:// www.cdc.gov/hai/organisms/acinetobacter.html (accessed on 15 June 2017).

20. Reinthaler FF, Posch J, Feierl G, et al. Antibiotic resistance of E. coli in sewage and sludge. Water Res 2003;37(8):1685-1690. DOI: 10.1016/ S0043-1354(02)00569-9.

21. Agrawal A, Pandey RS, Sharma B. Water pollution with special reference to pesticide contamination in india. J Water Resour Prot 2010;2(05):432. DOI: 10.4236/jwarp.2010.25050.

22. Al-Ahmad A, Daschner FD, Kümmerer K. Biodegradability of cefotiam, ciprofloxacin, meropenem, penicillin G, and sulfamethoxazole and inhibition of waste water bacteria. Arch Env Contam Toxicol 1999;37(2):158-163. DOI: 10.1007/s002449900501.

23. Vogel Al, Bassett J, J Mendham J, et al. Textbook of quantitative chemical analysis. 5th ed. Longman Scientific and Technical; 1989. 